Article

\title{
Integrating Sustainability into Higher Education Curricula through the Project Method, a Global Learning Strategy
}

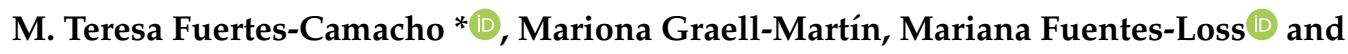 \\ M. Carmen Balaguer-Fàbregas $(\mathbb{D}$
}

Faculty of Education, Universitat Internacional de Catalunya, 08017 Barcelona, Spain; mgraell@uic.es (M.G.-M.); mafuentes@uic.es (M.F.-L.); mcbalaguer@uic.es (M.C.B.-F.)

* Correspondence: tfuertes@uic.es; Tel.: +34-932541800 or +34-935099250

Received: 30 November 2018; Accepted: 30 January 2019; Published: 1 February 2019

\begin{abstract}
Higher levels of material well-being lead almost inevitably to giving priority to individualism and personal advancement, often at the expense of civic conscience. A proposal for integrating sustainability into the curriculum is presented in the third year of the degree in Early Childhood Education at the Universitat Internacional de Catalunya (UIC). Projects on sustainable food are planned and elaborated to this aim. This study seeks to apply a global and systemic approach to solving socio-environmental problems and to check whether education for sustainable development (ESD) helps to develop and encourage actions that promote sustainable development. Quantitative research was conducted using a pre-test/post-test quasi experimental design separated by a period of didactic training in the project method. The results presented in this article show the students' sustainability competencies (SC) improve after working on didactic proposals in a global manner. It is concluded that elaborating competencies in education for sustainable development enables an integrated approach of knowledge, procedures, attitudes and values in teaching through promoting the project method in multidisciplinary and transdisciplinary teams, which enhances future teachers' sustainability competencies.
\end{abstract}

Keywords: sustainability competencies (SC); competencies in education for sustainability (ESD); project method; sustainable food; degree in early childhood education; teacher training; higher education; curricular sustainability; sustainable development goals; SDGs

\section{Introduction}

Planet degradation caused by unsustainable production and consumption patterns has ecological impacts that compromise the options of current and future generations [1]. The VUCA (volatility, uncertainty, complexity, and ambiguity) world we live in determines the labor market [2] and requires the functions and competencies exerted to include values and actions for change in addition to knowledge [3,4]. Training teachers for the education of future generations is therefore key to reach the objectives of Sustainable Development Goal 4 (SDG 4), which is based on ensuring inclusive, equitable and quality education promoting lifelong learning opportunities for all [5].

It is necessary for future teachers to acquire sustainability competencies and competencies in education for sustainable development (ESD) to bring about changes in society [6,7]. Sustainability competencies must be developed in higher education (HE) for future teachers to perform personal actions from this perspective [8]. In this respect, it should be noted that the Conference of Rectors of Spanish Universities (CRUE in Spanish) has drafted and approved documents that propose four core sustainability competencies in HE called SUST, which constitute a reference for this research [9]. 
According to the aforementioned documents approved by the General Assembly of the CRUE, integrating sustainability into the curriculum is essential. Teachers need to be empowered and professionally qualified as qualified teachers are key to quality education. They need to be given the necessary initial training and must be equipped with efficient and effective methodological strategies. It is unquestionable that today's professionals must be able to understand how their professional activity interacts with society and the environment, both locally and globally, in order to identify possible challenges, risks, and impacts. It is therefore crucial to transfer sustainability competencies to the teaching profession by developing competencies in education for sustainability, linking the teaching of sustainability to student learning $[10,11]$.

This article presents an empirical study conducted at the Universitat Internacional de Catalunya (UIC), based on ESD, which integrates scientific, linguistic and mathematical competencies applying the global methodology of the project method in the initial teacher training of third year students of the degree in Early Childhood Education. This proposal arises from the social need and commitment included in SDG 4 of the 2030 Agenda for Sustainable Development, which seeks to ensure quality education [5]. The main focus of the strategy is to teach the competency in ESD from a holistic and transformational perspective of education (SDG 4), addressing contents related to sustainable consumption and food (SDG 12) [5].

Following the educational model oriented towards learning competencies driven by the guidelines of the European Higher Education Convergence [12], the sustainability competencies and the competencies in EDS to be developed in curricula include the complex and integrated set of knowledge, procedures, attitudes, and values, which individuals draw upon in different contexts to solve real situations from an economic, social and environmental perspective [13].

\subsection{Sustainability Competencies and Competencies in Education for Sustainability in Initial Teacher Training}

Dealing with concepts of sustainability and education means entering into a debate that is difficult to solve. It is therefore considered that both the concept of education and the one of education are highly complex [14]. The relations established between both notions are therefore always influenced by circumstances and characteristics of participants and situations. Jicking \& Wals specify education is determined by numerous factors.: "How educators and curriculum theorists respond to these varied perspectives about education for sustainable development will depend on how they think about 'education' and the role education plays, or needs to play, in society. It will also depend on their image of 'educated persons', and their interactions within respective societies-in particular, the perceived role people are to assume in decision-making processes" ([14], p. 6).

"Sustainability competencies" or "competencies for sustainable development" are basic competencies that train people to adopt personal lifestyles ensuring a balance between economic growth, respect for the environment and social justice. "Sustainability competencies (SC)", which are of a more individual nature, are identified with "competencies for sustainable development" $[15,16]$. They must enable human beings to face challenges such as climate change, inequality, water shortage, hunger or responsible consumption, among others, from a global perspective that favors sustainable development.

Sustainable development is described by the United Nations Economic Commission for Europe (UNECE) Strategy for Education for Sustainable Development as being underpinned by an ethic of solidarity, equality, and mutual respect among people, countries, cultures, and generations; it is development in harmony with nature, meeting the needs of the present generation without compromising the ability of future generations to meet their own needs [17]. This definition of sustainable development is consistent with both the United Nations Declaration on the Right to Development, as set out in General Assembly resolution 41/128 of 4 December 1986, and the Rio Declaration on Environment and Development (United Nations Conference on Environment and Development, Rio de Janeiro, 3-14 June 1992). 
According to UNESCO, education is the main priority to promote sustainable development and is key to reach the sustainable development goals (SDGs) [5]. UNESCO has been promoting Education for Sustainable Development (ESD) since 1992. The competencies in education for sustainability or competencies for Sustainable Development (ESD) were developed by UNECE [17] and are based on Delors' four pillars [18] adapted to the field of sustainability. Although Delors did not specifically define the competency as such, in his report he did stress that education needs to be structured around four fundamental kinds of learning which, throughout people's lives, will be the pillars of learning: learning to know, i.e., acquiring the instruments of understanding; learning to do, to be able to influence one's own surroundings; learning to live together, to take part in and cooperate with others in all human activities; and learning to be, an essential process which includes parts of the other three pillars. The integration of those four methods of knowing converge into what we call competencies.

According to Cebrián and Junyent [6], they are competencies for professional development that enable transformation through education and develop the capacity of promoting changes in society. All this must allow for dialogue between disciplines from an integrating approach that promotes the capacity to listen so as to reach a more profound understanding that enables facing adversity [19] Higher education institutions have engaged in incorporating and institutionalizing sustainability into their curricula, research, and operations in order to educate future sustainability professionals as change agents for sustainable development $[19,20]$.

Twenty-first century learning requires engaging learners through applicable skills and knowledge and real-world connections to make learning relevant, personalized, and engaging [21]. Learning and innovations skills proposed by the P21 Framework for 21st Century Learning included creativity and Innovation, critical thinking and problem solving, communication and collaboration and life and career skills to navigate complex life and work environments [2,21]. Individuals as part of society must also have the power to act in complex situations in a sustainable manner. The framework clustering of competencies inspired by the report of the International Commission on Education to UNESCO presents a meaningful set of categories that reflect a wide range of learning experiences-including learning to know; learning to do; learning to live together; and learning to be-that addresses the development of one's personal attributes and ability to act with greater autonomy, judgement, and personal responsibility in relation to sustainable development [22]. Learning and learning-based change towards sustainability comprise the key focus. With the challenge of sustainable development, the advances need to be accompanied by changes in mind-sets, values, and lifestyles, and the strengthening of people's capacities to bring about change. [23].

Education should play an important role in enabling people to live together in ways that contribute to sustainable development. This can happen creating opportunities for learners to question their own lifestyles and the systems and structures that promote those lifestyles. Education for Sustainable Development (ESD) empowers people to change their way of thinking and to work towards a sustainable future. Knowledge, skills, and attitudes to manage sustainable development have become significant learnings of different career paths and they are needed for future change agents in the field of sustainable development [24]. The competencies in ESD are those of educators and future educators and these competencies go beyond the competencies that individual educators would have in order to provide a good quality education in their discipline [22]. ESD raises awareness of the complexity and dynamism of issues. It also plays a key role in making sustainable development understood and in ensuring it is applied in a specific way.

ESD aims to plan specific sustainable actions at all educational levels, favoring the development of competencies that allow people to think about their actions. This means they must take their own social, cultural, economic, and environmental impacts into account, both locally and globally. Integrating competencies for ESD in HE curricula may be seen as an important step to achieving sustainability in HE [25].

The 2030 Agenda for Sustainable Development was approved in 2015 by 150 Heads of State and Government that committed themselves to establish national frameworks to achieve the 17 universally 
applicable goals [26]. Those goals, which are not legally binding, are integrated and indivisible and balance the three dimensions of sustainable development: the economic, social and environmental. They build on the eight Millennium Development Goals (MDGs) approved in 2000 and recognise the ethical need to promote action initiatives and strategies that make them effective [5].

Previously, the association of University Leaders for a Sustainable Future (ULSF), signed the Talloires Declaration [27], a ten-point action plan for incorporating sustainability and environmental literacy in teaching, research, operations and outreach at universities. This declaration provides a comprehensive framework for sustainability, as well as inspiration and motivation to pursue environmental and sustainability initiatives on campus.

Emphasizing the importance of education is essential to build a more sustainable world [6]. Knowledge and know-how about sustainability are not enough. It is necessary to undertake actions that respond to real needs that commit and transform by impacting society, promoting real changes. The Bonn declaration [28] pointed out the importance of incorporating topics related to sustainable development by means of an integrated and systemic approach at all educational levels. At the same time, it recommends teacher education institutions, teachers and professors to develop and research sound pedagogical practice for that purpose [1].

ESD is crucial and confers quality to teaching and training systems [29]. It should be configured as an integral part of quality education, intrinsic to the concept of lifelong learning, as defined in SDG 4 mentioned earlier [5]. From this perspective, all educational institutions of both a formal and informal nature should include those competencies in their curricula [24], planning teaching and learning strategies applied in educational practices. ESD addresses learning contents and results in a holistic manner and considers active pedagogy and the learning environment as decisive factors for the development of key competencies in sustainability [19,30].

The need for a change in educational processes is at the basis of building the European Higher Education Area (EHEA). The Bologna process and the creation of new university degree programs stress the importance of training and assessing students using competencies. However, curricular sustainability involves not only including environmental content in the syllabus of different subjects. It also implies a paradigm shift in educational processes [31,32].

Starting from the complexity the concept itself poses, in order to ensure ESD, integrating and interdisciplinary teaching and learning approaches, such as the project method, are appropriate. They foster sustainability skills such as problem-solving, critical thinking [33], and the competency for action and communication [34]. Lambrechts and Van Petegem justify the connection between those skills and sustainability competencies: "The acquisition and assessment of competences for SD require different ways of teaching and learning which focus on experiential learning, reflective learning, participative learning, active learning, creativity, collaboration, problem solving, practice-based learning, transdisciplinary approach, and self-regulation (Sterling, 2004, Wals \& Jickling, 2002; Wals, 2010). This different way of teaching and learning is necessary for universities to contribute to a more sustainable society..." [35].

\subsection{Project Method as an Integrating Approach of Teaching and Learning Processes}

The project method has its origin in Dewey's functional learning [36,37] and in the didactic structure formulated by Kilpatrick [38], who proposed the project method as a global and competency-based learning model. This teaching and learning method complies with the three characteristics Lambrechts, et al. (2013) identify, mentioned in [35]: is interactive and participative, permits solving real community problems and is a research method that allows students to acquire instrumental skills and the development of critical and reflective thinking [35].

Within the framework of degrees in education, formative intentions linked to acquiring competencies for ESD are closely related to designing contextualized learning and to didactics that encourage global learning. The project method constitutes an excellent didactic model to achieve 
both objectives: being competent as educators in sustainability and promoting significant curricular learning in students.

Despite the doubts Kilpatrick's project method generated at first [39] with regard to the positive effect of leadership of students on their own learning, it has currently gained popularity thanks to the appearance of the methodology of project-based-learning. This method is founded on learning processes based on inquiry and the presentation of questions leading the learning process, adopting a constructivist Vygostkian-based approach.

In the case of Early Childhood Education it is considered the teacher has to be the one in charge of asking questions leading the learning process, which is why this methodology was used in our research, though maintaining the five features which, according to Pecore ([39], p. 159), project-based-learning must include: 1) a central project; 2) a constructivist focus on important knowledge and skills; 3) a driving activity in the form of a complex question, problem, or challenge; 4) a learner-driven investigation guided by the teacher; and 5) a real-world project that is authentic to the learner.

The theoretical evolution of those initial approaches has determined that work projects constitute a proposal of organizing knowledge, which consists of creating strategies related to processing information and to linking the different contents based on a hypothesis or real problem. Developing those strategies enable students to build up understanding from the transformation of information coming from different kinds of disciplinary knowledge [40].

From the point of view of global learning, learning projects do not constitute a sum of subjects, or even the combination of different disciplines in a common objective. Hernándes and Ventura [40] describe the globalization they present as the materialization of a psychological learning structure. Based on a socio-constructivist and interactive learning approach, these authors consider that students, when working on projects, experience a process of understanding thanks to the reconstructive and constructive tasks carried out using the information they have access to. Reconstructive understanding is considered to be the ability to access the basic ideas of a piece of information and place it within the framework of the work performed (global reconstruction). Constructive understanding is regarded as the capacity to generate new questions and new knowledge, based on that information.

Recent studies have established a framework aiming to help educators when creating and modernizing their classes to provide students with a whole set of sustainability competencies [41] although research concerning pedagogical approaches continues to be scarce.

The present study provides new information and answers the following research questions:

1. Does planning projects on sustainable food related to SDG 4 and SDG 12 improve future teachers' sustainability competencies?

2. Does the design and implementation of global didactic projects improve future teachers' competencies in ESD?

\section{Materials and Methods}

The research methodology used to conduct this analysis is based on a quantitative approach. The sample $\mathrm{n}=16$ consists of 16 subjects, third year students of the Degree in Early Childhood Education at the Universitat Internacional de Catalunya (UIC). It is a quasi-experimental pre-test/post-test design carried out with a group of students during a training program implemented between both tests [42]. The procedures followed were distributed in the following phases (Figure 1):

1. First phase:

- $\quad$ Performing the pre-test on student sustainability competencies (by means of a test validated by the education department of the government of Catalonia, the institution that decides on the curriculum of childhood education) 
2. Second phase:

- Performing the simultaneous training program of four specific didactics to develop subject specific competencies (SSC)

- Planning and development of projects by the students at the same time project-related content is taught in the different subjects

- Feedback in the university classroom

3. Third phase:

- Presentation of the projects designed by the students and assessment of the ESD competencies related to the degree specific competency (DSC) by the teachers in charge

4. Fourth phase:

- Performing the post-test

- Checking changes in student sustainability competencies

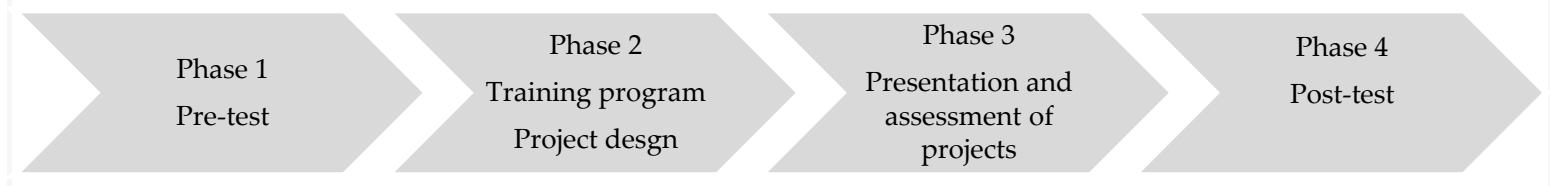

Figure 1. Research phases. Own work.

The instruments used to collect data corresponding to each phase of the project are summarised in Table 1 and are specified throughout this section. The criterion followed for choosing those individual sustainability competencies and not other competencies is justified because of its conceptual association with the current Early Childhood Education curriculum and because it is the objective of this research.

Table 1. Research phases, instruments, and Table 4 related data. Own work.

\begin{tabular}{|c|c|c|c|}
\hline & Phase & $\begin{array}{c}\text { Data Collection Instrument } \\
\text { and Table } 4\end{array}$ & Data Provided \\
\hline Phase 1 & Pre-test & $\begin{array}{c}\text { Instrument } 1 \text {. Rubric to assess } \\
\text { the students' sustainability } \\
\text { competency. SUST-CRUE, } \\
\text { Learning Objectives SDG } 4 \\
\text { and SDG } 12\end{array}$ & Pre-test assessments \\
\hline \multirow{4}{*}{ Phase 2} & $\begin{array}{c}\text { SSC Assessment Learning } \\
\text { Natural Sciences and Social } \\
\text { Sciences }\end{array}$ & $\begin{array}{c}\text { Table 4. Integrated SSC } \\
\text { assessment and Learning } \\
\text { Objective SDG } 12\end{array}$ & Subject assessments \\
\hline & $\begin{array}{l}\text { SSC Assessment Learning } \\
\text { Mathematics }\end{array}$ & $\begin{array}{c}\text { Table 4. Integrated SSC } \\
\text { assessment and Learning } \\
\text { Objective SDG } 12\end{array}$ & Subject assessments \\
\hline & $\begin{array}{l}\text { SSC Assessment Learning } \\
\text { Languages }\end{array}$ & $\begin{array}{c}\text { Table 4. Integrated SSC } \\
\text { assessment and Learning } \\
\text { Objective SDG } 12\end{array}$ & Subject assessments \\
\hline & $\begin{array}{l}\text { SSC Assessment Learning } \\
\text { Natural Sciences, Social } \\
\text { Sciences, and Mathematics. } \\
\text { Project Method }\end{array}$ & $\begin{array}{l}\text { Table 4. Integrated SSC } \\
\text { assessment and Learning } \\
\text { Objective SDG } 12\end{array}$ & Subject assessments \\
\hline
\end{tabular}


Table 1. Cont.

\begin{tabular}{llcl}
\hline Phase & $\begin{array}{c}\text { Data Collection Instrument } \\
\text { and Table 4 }\end{array}$ & Data Provided \\
\hline Phase 3 & Global assessment of project & $\begin{array}{c}\text { Instrument 2. Global } \\
\text { assessment rubric of the } \\
\text { competency in ESD. DSCs and } \\
\text { Learning Objective SGD 12 }\end{array}$ & Global assessment \\
Phase 4 & Post-test & $\begin{array}{c}\text { Instrument 1. Rubric to assess } \\
\text { the students' sustainability } \\
\text { competency. SUST-CRUE, } \\
\text { Learning Objectives SDG 4 } \\
\text { and SDG 12 }\end{array}$ & Post-test assessments \\
\cline { 2 - 4 } & Answer to research questions & $\begin{array}{c}\text { Table 4. Comparative analysis } \\
\text { of the data obtained from } \\
\text { instruments 1, 2 and from the } \\
\text { results of the assessments of } \\
\text { the subjects }\end{array}$ & $\begin{array}{c}\text { Data for comparative } \\
\text { analyses }\end{array}$ \\
\hline
\end{tabular}

The specific instruments used to collect data related to sustainability competencies and competencies in education for sustainability have different theoretical descriptions and justifications.

First, instrument 1 is described (Table 2). This instrument was used as a pre-test and post-test (phases 1 and 4 ) and serves to assess sustainability competencies. It is a rubric including three indicators and three levels of competency for each indicator: 1. Low, 2. Medium, and 3. High. They correspond to values from 1 to 10 as expressed in the table. Within this rubric, the lowest level corresponds to 1 and the highest corresponds to 3 . The results obtained through this rubric will enable answering question 1 and check whether students have improved their sustainability competencies.

Table 2. Instrument 1. Pre-test/post-test rubric for the assessment of the sustainability competency. Inspired by Miller (1990) [43] CRUE (2012) [9], UNESCO (2017) [5], Albareda et al. 2018 [44].

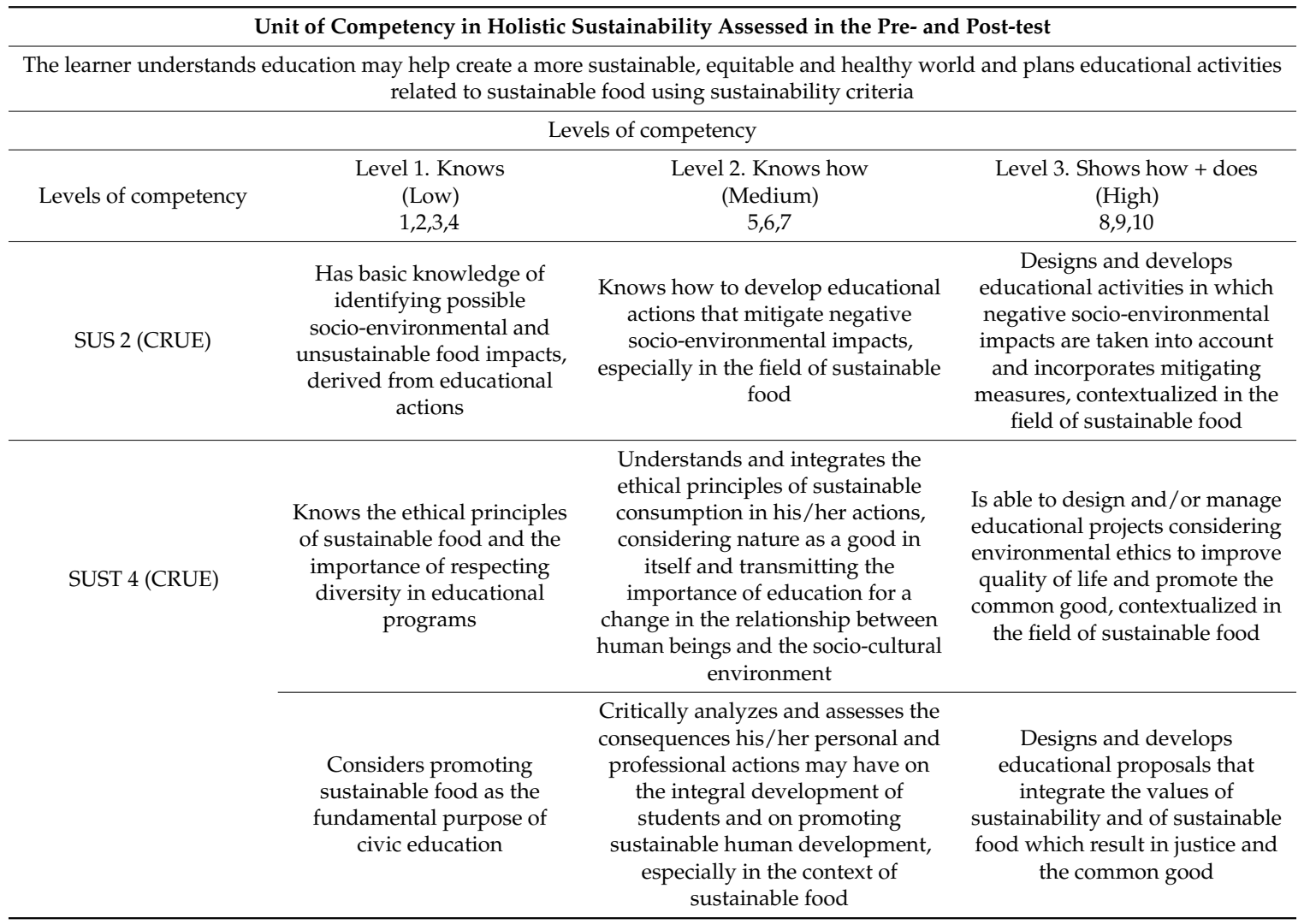


At a statistical level, consistent with the assessment systems applied at the university, it was considered appropriate to assess student achievement on a scale from 1 to 10 , although with regard to developing competencies, those values were put together to show the levels of competency acquired by the students. Data collecting was performed through correcting the written tests that combine multiple choice answers with open answer questions. In the case of the latter, the presence of contents appropriate to the demand was evaluated. At the content level, the test including the pre and post-test is related to a real problematic situation, based on sustainable food and consumption contents. Students have to interpret the different dimensions of sustainability and make decisions to improve them.

To justify the elaboration of instrument 1 (Table 2) the following references were used:

1. Two of the core competencies of a holistic dimension (SUST 2 and SUST 4) approved by the General Assembly of the CRUE [9] include the units of competency and the corresponding levels of competency developed within the framework of the EDINSOST project [44]. These two references were used to establish the general framework of sustainability competencies in HE assessed in the pre and post-test. The two core competencies selected were the following:

SUST 2-Competency in the sustainable use of resources and in the prevention of negative impacts on the natural and social environment

SUST 4-Competency in the application of ethical principles related to the values of sustainability in personal and professional behavior.

To define key sustainability competencies, several authors elaborated different proposals to incorporate them in higher education. Based on Wiek et al. [31], Rieckmann [19], Sleurs [3] and considering the Spanish context we find ourselves in, the choice of those two competencies from the ones established by the CRUE can be justified [9]

The content of this competency is related to systemic (natural and social environment) and anticipatory thinking (prevention of negative impacts) [19]. With regard to Sleurs' [3] systemic thinking, he affirms the competencies teachers need to elaborate must consider the individual, institutional and social dimension of the teacher (the teacher as an individual-SC and the teacher in the education institution and in the society).

The content of this competency is related to critical thinking (personal and professional behavior) [19].

According to Wiek et al. ([31], p. 204), we embrace the convergence that sustainability education should enable students to analyze and solve sustainability problems, to anticipate and prepare for future sustainability challenges, as well as to create and seize opportunities for sustainability. Because sustainability problems and challenges have specific characteristics, analysing and solving sustainability problems requires a particular set of interlinked and interdependent key competencies. For this reason, our selection of the CRUE's competencies is linked to systemic, anticipatory and critical thinking [19] and also includes the teacher as an individual and the teacher in the society Sleurs [3].

2. Two of the learning objectives from the SDGs: SDG 4-Quality education and SDG 12-Responsible consumption and production:

Cognitive learning objective 1 (CLO 5) - SDG 4. The learner understands the important role of education and lifelong learning opportunities for all (formal, non-formal and informal learning) as main drivers of sustainable development, for improving people's lives and for achieving the SDGs [5] (p. 18).

Behavioral learning objective 1 (BLO 1) - SDG 12. The learner is able to plan, implement, and evaluate activities using existing sustainability criteria [5] (p. 34).

These learning objectives served to specify the units of holistic competency and the levels of acquisition of the two core competencies of the CRUE [9] included in Table 2 related to the topics of the projects developed based on sustainable food.

According to Miller [43], the first two levels are knowledge (knows) and how to apply it to specific cases (knows how) that refer to the field of cognition of a more professional nature. At the level immediately above those two levels, we find competency when it is measured in environments 
where the professional must show or show how he/she is capable of doing or what the professional would actually do in practice. This last level, according to Miller [43], refers to behavior, to knowledge that must accompany knowing how to be and knowing how to act in a manner consistent with the situation [45].

Second, instrument 2 is described (Table 3). It is a joint assessment rubric for the global projects. This rubric is used in the third research phase. Its objective is to collect the shared assessment of the teachers who have taught the specific didactics separately and who must now evaluate the didactic integration of the students based on the contents in sustainable education and, more particularly, sustainable food.

To justify that the rubric provides data on the development of competencies in education for sustainability, the indicators listed in Table 3 were drawn up based on a degree specific competency (DSC) achieved with behavioral learning objective 1 of SDG 12.

In a complementary manner, items corresponding to the didactic treatment of the aforementioned subjects have been adapted. This instrument contributes to providing the necessary data to subsequently answer the second research question.

Instrument 2 was applied from observing the presentations of the students who took part in the research. The university teachers assessed the presentations of the projects based on the same rubric after which the results were agreed on. The assessment scales follow the same criteria as the ones described for the instrument. In other words, the scores are out of 10 and show the level of competency attained (low, medium, high).

Third, Table 4 is described. The purpose of this table is to present all the research data in order to make a comparative analysis between them. It is a global table, from whose study the answer to the second research question is obtained and implicitly also to the first one. It allows checking the improvement of competencies in ESD (development of the training process). At the same time, it enables comparing the improvement of sustainability competencies (pre-test and post-test). The use of this table was developed during the fourth research phase.

The procedures performed for its completion are varied. The results of instrument 1 (Table 2) were collected, corresponding to the pre-test and post-test, related to the improvement of the sustainability competency; the results of the subject assessments were recorded in relation to their respective subject specific competencies (SSC) adapted to SDGs 4 and 12; the results obtained through instrument 2 (Table 3) related to the competency in ESD shown in the projects carried out by the students, which were also adapted to SDGs 4 and 12, were noted.

The elaboration of this instrument is justified on the basis of the data provided by the UN 2030 Agenda for Sustainable Development [5]. The (cognitive, socio-emotional, or behavioral) learning objectives included in goals 4 (SDG 4) and 12 (SDG 12) of the 2030 Agenda for Sustainable Development [5] are closely related to the fields of knowledge, of know-how and of the personal commitment associated with knowing how to be and how to live with others [18]. For this reason, in this study, the learning objectives of the SDGs have been connected with the competencies of the four subjects of the Degree in Early Childhood Education (learning natural sciences and social sciences (LNSSS), Learning Mathematics (LM); learning languages (LL), and the project method (PM)) taught to the same students by four teachers during the same semester.

The objective of Table 4 is to show it is the coordination, and not the juxtaposition, of the content of the four subjects involved in the study that enables addressing sustainability from a holistic approach, taking the environmental, economic, and social dimensions of sustainability into account.

From a functional point of view, Table 4 allows presenting the results of instruments 1 and 2 together and the assessment of the didactic projects. Those projects, in accordance with the methodological characteristics mentioned in the introduction and with their content, enable assessing competencies for education in sustainable development (ESD). The justification of the relation between the project methodology and ESD is found in Table 5. 
Table 3. Instrument 2. Global assessment rubric of the competency in ESD. Source: Adaptation SUST (CRUE, 2012 [9]; Albareda et al. 2018 [42,44].

\begin{tabular}{|c|c|c|c|c|c|c|c|c|c|c|c|c|c|c|c|c|c|}
\hline \multicolumn{18}{|c|}{ Competencies in Education for Sustainability } \\
\hline \multicolumn{18}{|c|}{$\begin{array}{l}\text { DSC adapted to SDG 12. Encourage responsibility related to professional development: analyze, reflect on and develop points of view that allow students to plan, implement and } \\
\text { evaluate consumption-related using existing sustainability criteria }\end{array}$} \\
\hline \multirow{2}{*}{ Indicators } & \multirow[b]{2}{*}{ 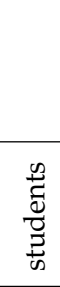 } & \multicolumn{3}{|c|}{$\begin{array}{l}\text { Interrelates food with the } \\
\text { environment and } \\
\text { socio-economic aspects }\end{array}$} & \multicolumn{3}{|c|}{$\begin{array}{l}\text { Presents an educational } \\
\text { project promoting } \\
\text { sustainable food in a } \\
\text { coordinated manner }\end{array}$} & \multicolumn{3}{|c|}{$\begin{array}{l}\text { Knows how to work } \\
\text { cooperatively and } \\
\text { responsibly }\end{array}$} & \multicolumn{3}{|c|}{$\begin{array}{l}\text { Justifies didactic learning } \\
\text { and thoughts developed } \\
\text { throughout the project }\end{array}$} & \multicolumn{4}{|c|}{$\begin{array}{l}\text { Communicates well and } \\
\text { uses appropriate } \\
\text { vocabulary }\end{array}$} \\
\hline & & $\begin{array}{c}\text { Low } \\
1,2,3,4\end{array}$ & $\begin{array}{c}\text { Medium } \\
5,6,7\end{array}$ & $\begin{array}{l}\text { High } \\
8,9,10\end{array}$ & $\begin{array}{c}\text { Low } \\
1,2,3,4\end{array}$ & $\begin{array}{l}\text { Medium } \\
5,6,7\end{array}$ & $\begin{array}{l}\text { High } \\
8,9,10\end{array}$ & $\begin{array}{l}\text { Low } \\
1,2,3,4\end{array}$ & $\begin{array}{l}\text { Medium } \\
5,6,7\end{array}$ & $\begin{array}{l}\text { High } \\
8,9,10\end{array}$ & $\begin{array}{l}\text { Low } \\
1,2,3,4\end{array}$ & $\underset{1,2,3,4}{\text { Medium }}$ & $\begin{array}{l}\text { High } \\
8,9,10\end{array}$ & $\begin{array}{c}\text { Low } \\
1,2,3,4\end{array}$ & $\begin{array}{c}\text { Medium } \\
5,6,7\end{array}$ & $\begin{array}{l}\text { High } \\
8,9,10\end{array}$ & $\begin{array}{l}\text { Final } \\
\text { average }\end{array}$ \\
\hline \multicolumn{18}{|l|}{$\begin{array}{l}\text { Welcome to } \\
\text { Slowtering }\end{array}$} \\
\hline \multicolumn{18}{|l|}{$\begin{array}{l}\text { Luigi, shall we } \\
\text { make an } \\
\text { eco-pizza? }\end{array}$} \\
\hline \multicolumn{18}{|l|}{ Sugars } \\
\hline \multicolumn{18}{|l|}{$\begin{array}{l}\text { Eco-friendly } \\
\text { snacks }\end{array}$} \\
\hline Eco-smoothies & & & & & & & & & & & & & & & & & \\
\hline
\end{tabular}


Table 4. Interrelation between the sustainability competency and the competency in education for sustainability.

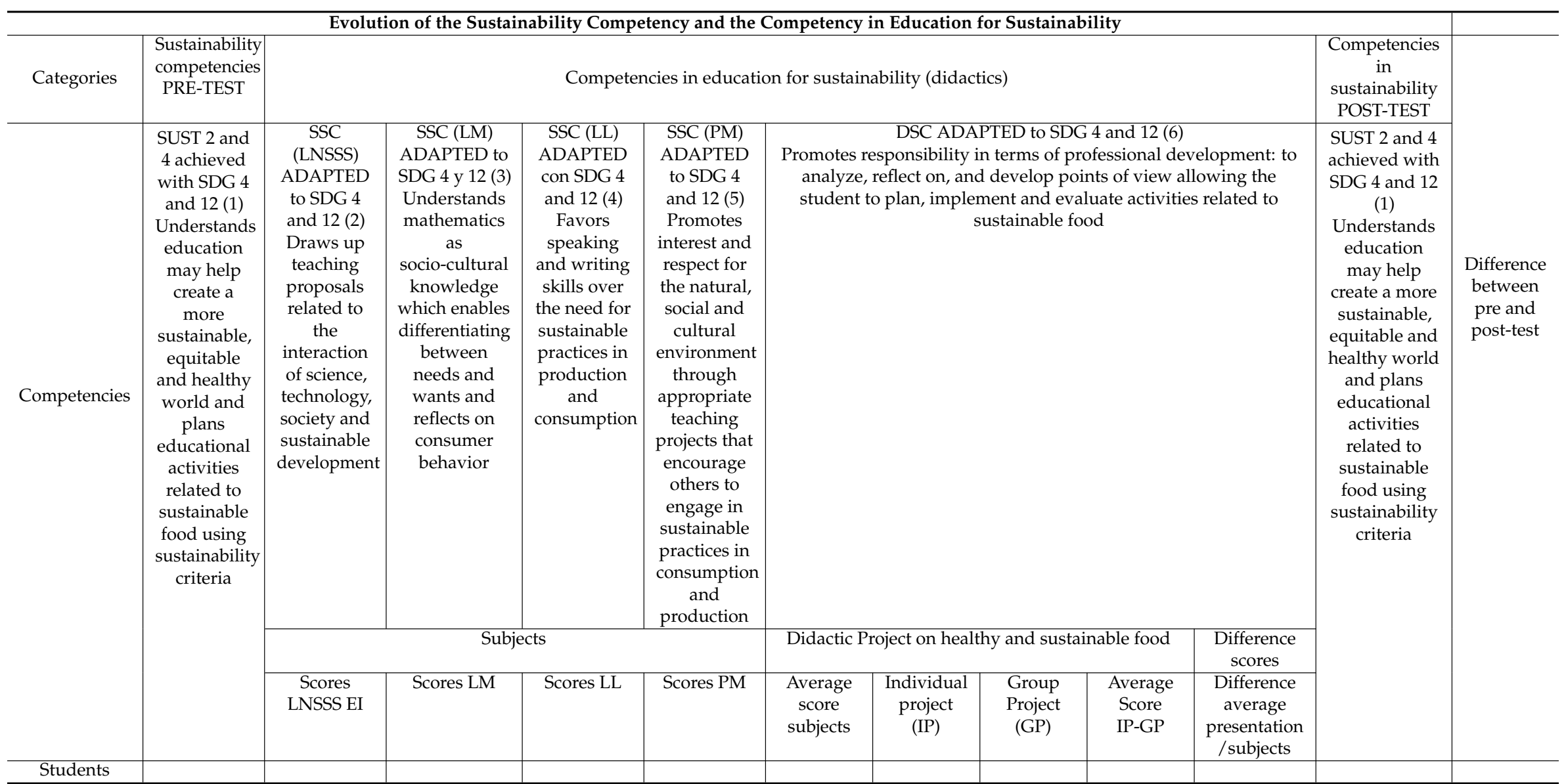


Table 5. Interrelation between the competency of the subject and the learning objectives SDG 4 and SDG 12.

\begin{tabular}{|c|c|c|c|c|c|}
\hline $\begin{array}{c}\text { Items Numbered in } \\
\text { Table } 4\end{array}$ & $\begin{array}{l}\text { Cognitive Learning } \\
\text { Objective (CLO) }\end{array}$ & $\begin{array}{l}\text { Behavioral Learning } \\
\text { Objective (BLO) }\end{array}$ & $\begin{array}{l}\text { Subject Specific } \\
\text { Competency (SSC) }\end{array}$ & $\begin{array}{c}\text { Socio-emotional Learning } \\
\text { Objective }\end{array}$ & $\begin{array}{c}\text { Degree Specific } \\
\text { Competency (DSC) }\end{array}$ \\
\hline $\begin{array}{l}\text { 1. Understands education } \\
\text { may help create a more } \\
\text { sustainable, equitable and } \\
\text { healthy world and plans } \\
\text { educational activities } \\
\text { related to sustainable food } \\
\text { using sustainability } \\
\text { criteria }\end{array}$ & $\begin{array}{l}\text { Cognitive learning objective } 5 \\
\text { (CLO 5) from SDG 4-The } \\
\text { learner understands the } \\
\text { important role of education } \\
\text { and lifelong learning } \\
\text { opportunities for all (formal, } \\
\text { non-formal and informal } \\
\text { learning) as main drivers of } \\
\text { sustainable development, for } \\
\text { improving people's lives and } \\
\text { for achieving the SDGs }\end{array}$ & $\begin{array}{l}\text { Behavioral learning } \\
\text { objective } 1 \text { (BLO 1) from } \\
\text { SDG 12-The learner is } \\
\text { able to plan, implement } \\
\text { and evaluate } \\
\text { consumption-related } \\
\text { activities using existing } \\
\text { sustainability criteria [5] } \\
\text { (pp. 18,34). }\end{array}$ & & & \\
\hline $\begin{array}{l}\text { 2. Draws up teaching } \\
\text { proposals related to the } \\
\text { interaction of science, } \\
\text { technology, society and } \\
\text { sustainable development }\end{array}$ & & & $\begin{array}{l}\text { Subject specific } \\
\text { competency SSC 39-To } \\
\text { draw up teaching } \\
\text { proposals related to the } \\
\text { interaction of science, } \\
\text { technology, society and } \\
\text { sustainable development } \\
\text { of the subject Learning } \\
\text { Natural Sciences and } \\
\text { Social Sciences in the } \\
\text { Degree in Early } \\
\text { Childhood Education }\end{array}$ & $\begin{array}{l}\text { Socio-emotional learning } \\
\text { objective } 2 \text { from SDG 12-The } \\
\text { learner (in our case future } \\
\text { pre-primary teachers) is able } \\
\text { to encourage others to engage } \\
\text { in sustainable practices in } \\
\text { consumption and production } \\
\text { [5,46] (p. 34). }\end{array}$ & \\
\hline $\begin{array}{l}\text { 3. Understands } \\
\text { mathematics as } \\
\text { socio-cultural knowledge } \\
\text { which enables } \\
\text { differentiating between } \\
\text { needs and wants and } \\
\text { reflects on consumer } \\
\text { behavior }\end{array}$ & & & $\begin{array}{c}\text { Subject specific } \\
\text { competency SSC 35-To } \\
\text { understand mathematics } \\
\text { as socio-cultural } \\
\text { knowledge of the subject } \\
\text { Learning Mathematics in } \\
\text { the Degree in Early } \\
\text { Childhood Education }\end{array}$ & $\begin{array}{l}\text { Socio-emotional learning } \\
\text { objective } 3 \text { from SDG } 12-\text { The } \\
\text { learner is able to differentiate } \\
\text { between needs and wants to } \\
\text { reflect on their own } \\
\text { individual consumer } \\
\text { behavior in light of the needs } \\
\text { of the natural world, other } \\
\text { people, cultures and } \\
\text { countries, and future } \\
\text { generations }[5,47](p .3,4) \text {. }\end{array}$ & \\
\hline
\end{tabular}


Table 5. Cont.

\begin{tabular}{|c|c|c|c|c|c|}
\hline $\begin{array}{c}\text { Items Numbered in } \\
\text { Table } 4\end{array}$ & $\begin{array}{c}\text { Cognitive Learning } \\
\text { Objective (CLO) }\end{array}$ & $\begin{array}{l}\text { Behavioral Learning } \\
\text { Objective (BLO) }\end{array}$ & $\begin{array}{l}\text { Subject Specific } \\
\text { Competency (SSC) }\end{array}$ & $\begin{array}{c}\text { Socio-emotional Learning } \\
\text { Objective }\end{array}$ & $\begin{array}{c}\text { Degree Specific } \\
\text { Competency (DSC) }\end{array}$ \\
\hline $\begin{array}{l}\text { 4. Favors speaking and } \\
\text { writing skills over the } \\
\text { need for sustainable } \\
\text { practices in production } \\
\text { and consumption }\end{array}$ & & & $\begin{array}{l}\text { Subject specific } \\
\text { competency SSC 43-To } \\
\text { foment speaking and } \\
\text { writing skills of the } \\
\text { subject Learning } \\
\text { Languages in the Degree } \\
\text { in Early Childhood } \\
\text { Education }\end{array}$ & $\begin{array}{l}\text { Socio-emotional learning } \\
\text { objective } 1 \text { from SDG } 12 \text { - The } \\
\text { learner is able to } \\
\text { communicate the need for } \\
\text { sustainable practices in } \\
\text { production and consumption. } \\
\text { [5,48] (p. } 34 \text { ). }\end{array}$ & \\
\hline $\begin{array}{l}\text { 5. Promotes interest and } \\
\text { respect for the natural, } \\
\text { social and cultural } \\
\text { environment through } \\
\text { appropriate teaching } \\
\text { projects that encourage } \\
\text { others to engage in } \\
\text { sustainable practices in } \\
\text { consumption and } \\
\text { production }\end{array}$ & & & $\begin{array}{l}\text { Subject specific } \\
\text { competency SSC 40-To } \\
\text { promote interest and } \\
\text { respect for the natural, } \\
\text { social and cultural } \\
\text { environment through } \\
\text { appropriate teaching } \\
\text { projects in the subject } \\
\text { Learning Natural Sciences, } \\
\text { Social Sciences and } \\
\text { Mathematics. It integrates } \\
\text { the project method in the } \\
\text { Degree in Early } \\
\text { Childhood Education }\end{array}$ & $\begin{array}{l}\text { Socio-emotional learning } \\
\text { objective } 2 \text { from SDG 12-The } \\
\text { learner is able to encourage } \\
\text { others to engage in } \\
\text { sustainable practices in } \\
\text { consumption and production. } \\
\text { This relationship allows us to } \\
\text { link SDG 4-Quality } \\
\text { education and SDG } \\
\text { 12-Responsible } \\
\text { consumption and production } \\
\text { [5,49] (p. 34). }\end{array}$ & \\
\hline $\begin{array}{l}\text { 6. Promotes responsibility } \\
\text { in terms of professional } \\
\text { development: to analyze, } \\
\text { reflect on, and develop } \\
\text { points of view allowing } \\
\text { the student to plan, } \\
\text { implement and evaluate } \\
\text { activities related to } \\
\text { sustainable food }\end{array}$ & & $\begin{array}{l}\text { Behavioral learning } \\
\text { objective } 1 \text { from SDG } \\
\text { 12-The learner is able to } \\
\text { plan, implement and } \\
\text { evaluate activities using } \\
\text { existing sustainability } \\
\text { criteria [5,46-49] (p. 34). }\end{array}$ & & & $\begin{array}{l}\text { Degree specific } \\
\text { competency DSC 7-To } \\
\text { promote responsibility in } \\
\text { terms of professional } \\
\text { development: to analyze, } \\
\text { reflect on, and develop } \\
\text { points of view about the } \\
\text { profession and teaching } \\
\text { skills, to know how to } \\
\text { make these clear and how } \\
\text { to bring them up to date }\end{array}$ \\
\hline
\end{tabular}


Subsequently, the post-test, allows checking whether improvement is observed in the development of the same sustainability competencies assessed in the pre-test.

In Table 4, the competencies of sustainable development resulting from the interrelation between the competencies of the subjects and the learning objectives of SDG 4 and SDG 12 can be observed. While Table 1 explains the different research phases, in Table 4 the results obtained in each research phase are shown to have an overall idea of the performance of the different students in each phase.

The usefulness of Table 4 lies in the possibility of presenting the results of instruments 1 and 2 together and the assessments of the didactic projects that enabled assessing the competencies in Education for Sustainable Development (ESD). The justification of the relation between the project methodology and ESD is found in Table 5.

The concepts that appear in the table are explained below in Table 5:

In short, the methodological model addressed through the objectives of sustainable development and subject competencies is the following (Table 6):

Table 6. Training design: Achieving SSC and DSC with the SDGs.

\begin{tabular}{|c|c|}
\hline \multicolumn{2}{|c|}{ PRE-TEST } \\
\hline \multicolumn{2}{|c|}{ TRAINING PROGRAM } \\
\hline Subject competencies [46-49] & Socio-emotional learning objectives (SDG 12) [5] (p. 34) \\
\hline $\begin{array}{c}\text { To draw up teaching proposals related to the } \\
\text { interaction of science, technology, society and } \\
\text { sustainable development }\end{array}$ & \multirow{4}{*}{$\begin{array}{c}\text { The learner (in our case future pre-primary teachers) is able to } \\
\text { encourage others to engage in sustainable practices in } \\
\text { consumption and production } \\
\text { The learner is able to differentiate between needs and wants } \\
\text { and to reflect on their own individual consumer behavior in } \\
\text { light of the needs of the natural world, other people, cultures } \\
\text { and countries, and future generations } \\
\text { The learner is able to communicate the need for sustainable } \\
\text { practices in production and consumption }\end{array}$} \\
\hline $\begin{array}{l}\text { To understand mathematics as socio-cultural } \\
\text { knowledge }\end{array}$ & \\
\hline To foment speaking and writing skills & \\
\hline $\begin{array}{l}\text { To promote interest and respect for the natural, social } \\
\text { and cultural environment through appropriate } \\
\text { teaching projects }\end{array}$ & \\
\hline Competencies of project presented & Behavioral learning objective (SDG 12) [5] (p. 34) \\
\hline $\begin{array}{l}\text { To promote responsibility in terms of professional } \\
\text { development: to analyze, reflect on, and develop } \\
\text { points of view about the profession and teaching } \\
\text { skills, to know how to make these clear and how to } \\
\text { bring them up to date }\end{array}$ & $\begin{array}{c}\text { The learner is able to plan, implement, and evaluate } \\
\text { consumption-related activities using existing sustainability } \\
\text { criteria }\end{array}$ \\
\hline \multicolumn{2}{|c|}{ POST-TEST } \\
\hline
\end{tabular}

Once the different instruments used to collect data have been described and justified, an outline is provided of how the aforementioned training program (phase 2 of the research) has been carried out. It was applied to students between the pre-test and the post-test to favor the development of competencies in education for sustainability.

It involves teaching training based on the design of cross-cutting learning projects (linguistic, mathematical, and experimental competencies), whose content (Table 7) was associated with the topics and learning methods suggested for SDG 4 and SDG 12 in the UNESCO document [5] (p. 19, 35):

Table 7. Selection of topics and learning methods.

\begin{tabular}{cc}
\hline Topics & Learning Methods \\
\hline $\begin{array}{c}\text { SDG 4-Knowledge, values, skills, and behavior needed } \\
\text { to promote sustainable development [5] (p. 19) }\end{array}$ & $\begin{array}{c}\text { SDG 4-Plan and run an ESD project at a school } \\
\text { or university [5] (p. 19) }\end{array}$ \\
\hline SDG 12-Food production and consumption [5] (p. 35) & $\begin{array}{c}\text { SDG 12-Develop an enquiry-based project on } \\
\text { sustainable food [5] (p. 35). }\end{array}$ \\
\hline
\end{tabular}


Through the subjects, the students planned the projects in groups and the common theme was sustainable food (Table 8). The procedures and analyses of the project method, together with the contents related to sustainability, were aimed at developing the competency in education for sustainability. The characteristics of the projects are specified in the table below.

Table 8. Description purpose of the projects.

\begin{tabular}{cc}
\hline Project Name & Project Aims \\
\hline Luigi, shall we make an eco-pizza? & $\begin{array}{c}\text { To work on all the concepts through preparing pizzas made with } \\
\text { sustainable foods, to motivate children to address sustainability }\end{array}$ \\
\hline Welcome to Slowtering & $\begin{array}{c}\text { To become aware of the importance of a healthy diet through the } \\
\text { slow food movement }\end{array}$ \\
\hline Eco-friendly snacks & $\begin{array}{c}\text { Introduce children to the idea that a healthy diet is defined as } \\
\text { being sufficient, balanced, safe, nutritionally adequate, adapted to } \\
\text { the person eating and to the environment }\end{array}$ \\
\hline Sugars & $\begin{array}{c}\text { Work on and become aware of the properties of sugar in food } \\
\text { Make an eco-smoothie with organic fruit and vegetables for } \\
\text { pre-school children aged five, teaching them which sustainable } \\
\text { products are used }\end{array}$ \\
\hline
\end{tabular}

The operational structure of a project consists of different phases. First of all, students choose a topic. It is a democratic process favoring the choice of topics that are of interest to the students. In this research, the teachers proposed the topics with the aim of contributing to ESD, taking the interests and preferences of the students into account to reinforce motivational processes.

Spaces for debate are then created to promote the determination of hypotheses, which are linked to the following questions: what do you know about this topic (determination of prior knowledge)?; what else would you like to know about the subject?; and, how can we find information about it?

Once the initial information was collected through a hypothesis or a real problem, it is the teacher, in this case the future teacher, who must organise how to propose activities that lead to the solution of the initial approach. The following are the teachers' main tasks: they must determine the central theme of the project; they must include objectives, contents and activities, which can be developed throughout the project; they must select the information that may provide solutions or raise new questions for the participants; they must create a group work environment that encourages participation and acceptance of challenges; they must use materials and technologies of different nature that facilitate understanding; they must plan how to perform the assessment sequence (initial, formative, and summative); and finally, they must reflect on the effectiveness of the project implemented to make decisions about its modifications, always with the aim of improving it.

The global proposal evaluated in this research was generally based on monitoring this method, achieved with the objectives, contents, and methodologies necessary to improve the competencies in education for sustainability.

For the data analysis, given the characteristics of the research, the Wilcoxon signed-rank test, a test for non-parametric samples, was performed, providing statistical justification to the conclusions of our research.

\section{Discussion and Conclusions}

Once the research method and the instruments enabling data collection are designed, the results linked to the research questions are presented. 1) Does planning projects on sustainable food related to SDG 4 and SDG 12 improve future teachers' sustainability competencies? 2) Does the design and implementation of global didactic projects improve future teachers' competencies in ESD? 
In order to answer the first question, the 16 third year students of the degree in Early Childhood Education, whose average age is 22.7, performed a pre-test and a post-test. The results of these tests show the scores each student obtained in the pre-test and the post-test (Figure 2).

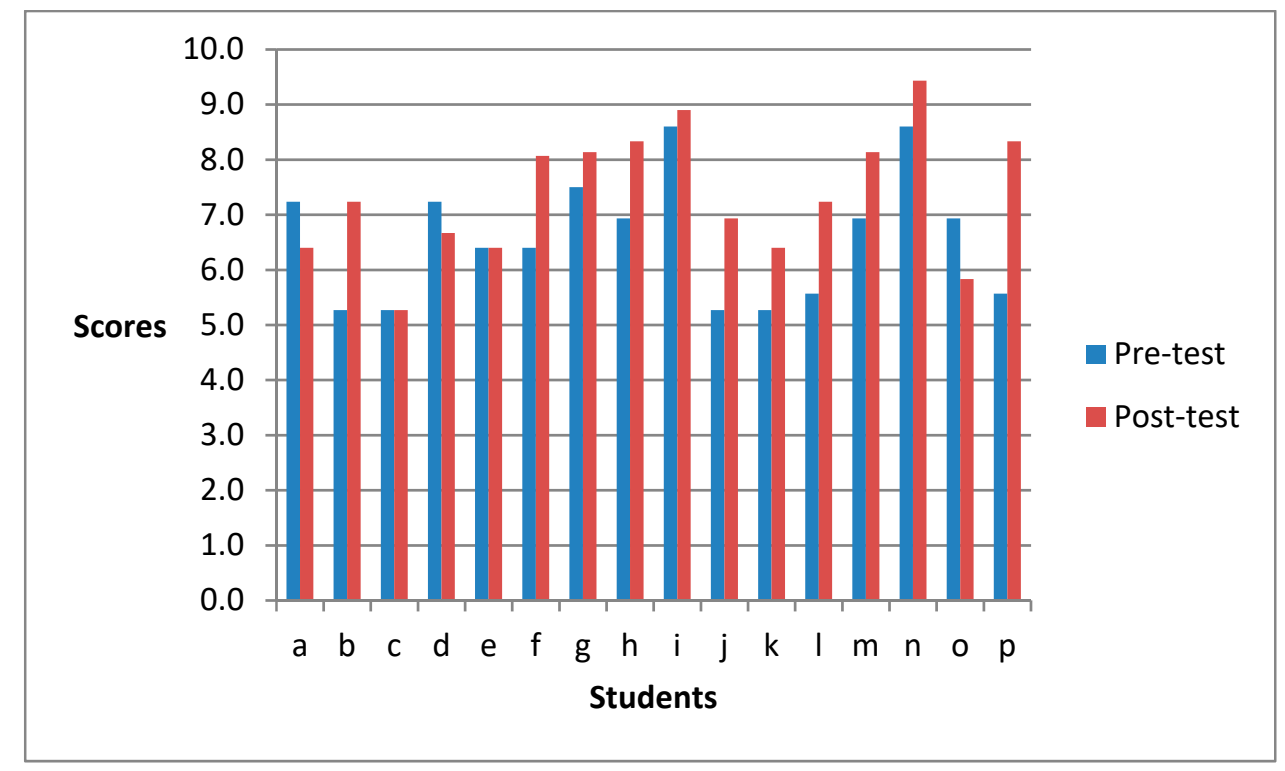

Figure 2. Results of the pre-test and post-test.

The results of the reliable and validated test applied in the pre and post-test, as shown in Figure 2, reveal the average score of the students in the pre-test was 6.6 points out of 10 , and 7.4 out of 10 in the post-test. The standard deviation is 1.13 in the pre-test, and 1.16 in the post-test, which indicates the students' results hardly deviate from the average. The difference between the results of the two tests is shown in Table 9.

Table 9. Difference between the results of the pre-test and the post-test.

\begin{tabular}{ccccccccccccccccc}
\hline Students & $\mathbf{a}$ & $\mathbf{b}$ & $\mathbf{c}$ & $\mathbf{d}$ & $\mathbf{e}$ & $\mathbf{f}$ & $\mathbf{g}$ & $\mathbf{h}$ & $\mathbf{i}$ & $\mathbf{j}$ & $\mathbf{k}$ & $\mathbf{1}$ & $\mathbf{m}$ & $\mathbf{n}$ & $\mathbf{o}$ & $\mathbf{p}$ \\
\hline $\begin{array}{c}\text { Difference } \\
\text { Pre-test/Post-test }\end{array}$ & -0.8 & 2 & 0 & -0.6 & 0 & 1.7 & 0.6 & 1.4 & 0.3 & 1.7 & 1.1 & 1.7 & 1.2 & 0.8 & -1.1 & 2.8 \\
\hline
\end{tabular}

A Wilcoxon signed-rank test indicated that the difference between the scores in the pre-test and the post-test are statistically significant $(z=-2514, p<0.012)$, given the fact that the $\mathrm{p}$-value is lower or equal than 0.5. From the results extracted (Table 9), a positive difference is observed in 11 students out of $16(69 \%)$, three students present a negative difference (19\%) and two did not present any difference $(12 \%)$.

The statistically significant difference between the scores of the pre-test and the post-test attained by the students allows us to affirm the improvement of core sustainability competencies (SUST2 and SUST4 of the CRUE [9] achieved with Cognitive Learning Objective 1 (CLO 1)-SDG 4 [5] (p. 18); and Behavioral Learning Objective 1 (BLO 1)-SDG 12 [5] (p. 34).

$69 \%$ of the students improved the sustainability competencies thanks to a training program (Table 4) that involved coordinated work in the four subjects and planning and designing a project on sustainable food (SDG 12). The results provide data on the group's overall improvement in sustainability competencies after developing the competency in education for sustainability through the project method.

As mentioned in the theoretical framework, unsustainable production and consumption patterns in today's world, instability, as well as inequality between people and regions [50], require us to prepare new generations not only for them to acquire knowledge, but also so that they can perform 
actions to achieve societal transformation [1,2,4]. Working on real problems using the project method is an effective tool to integrate knowledge, know-how, and knowing how to be and how to live with others, as stated by Delors [18].

To answer the second research question- Does the design and implementation of global didactic projects improve future teachers' competencies in ESD?- two averages are compared: the first one is the result of the scores obtained in the projects elaborated in groups and the score of the individual presentation. The second average arises from the assessments of the four subjects. To obtain these two averages the following results were used:

The first average (Table 11) is obtained from:

- The scores obtained in the projects elaborated in groups-instrument 2 (Table 10)

- The scores obtained in the individual presentation of the projects (Table 11)

The second average (Table 11) is obtained from:

- The scores obtained in the assessment of each subject (Table 11)

In Table 10 the indicators linked with the degree specific competency (DSC), are closely related to Behavioral Learning Objective 1 of SDG 12-The learner is able to plan, implement and evaluate activities using existing sustainability criteria [5] (p. 34).

Regarding the five indicators assessed, it is observed that the groups obtain an average higher than 9 out of $10 \mathrm{in}$ : communication, using appropriate vocabulary (9.4); working cooperatively and responsibly (9.3); and, finally, in the presentation of the sustainable food projects (9.2).

The results shown in Table 10 confirm the groups developed the SSC adapted to SDG 12: "Encourage responsibility related to professional development: analyze, reflect on, and develop points of view that allow students to plan, implement and evaluate consumption-related aspects using existing sustainability criteria."

With respect to the final average, the scores obtained by each group were very high, the minimum being 8 and the maximum 9.5 out of 10 . The overall average of all the groups was 8.9 . These values indicate the in-depth development of the competency in education for sustainable development (ESD) at the group level.

Table 11 includes the results of the competency in education for sustainability per student. It is represented by 10 columns. The first one identifies the students, the following four are the scores corresponding to the assessments of the specific competencies (SSC) of the subjects adapted to the corresponding SDG mentioned earlier. The sixth one shows the average of the scores of the four subjects. The seventh, eighth, and ninth column show the individual scores, the group scores and the average of the previous two (the individual score and the group project score respectively). The last column shows the difference between the two averages, those of the subjects and of the project).

The average of the assessments of the subject specific competencies (SSC) is very high, exceeding in all cases 7 points out of 10. If we take into account the difference of the average of the scores of the four subjects involved and the overall result of the assessment of the project, it is observed that $87.5 \%$ of the students obtain a positive difference, that is, they attain better marks in the global project than in the average of the different subjects. This difference allows observing how the assessment of the competency in education for sustainability or ESD through the holistic activity-the project method-obtains a higher score than the assessment of ESD per subject.

This positive difference between the average of the marks of the subjects and the mark of the assessment of the project, in favor of the latter, indicates that the project method favors the fulfilment of the Behavioral Learning Objective 1 from SDG 12-“"The learner is able to plan, implement and evaluate consumption-related activities using existing sustainability criteria" [5] (p. 34), through multidisciplinary and transdisciplinary work performed in different subjects. It is worth recalling that the competencies of the coordinated subjects developed on subject specific competencies (SSC) 35, 39, 40, and 43 of the curricula of the Degree in Early Childhood Education through the following 
learning objectives of the SDGs [5] (p. 34): (1) Socio-emotional Learning Objective 3 of SDG 12-The learner is able to differentiate between needs and wants and to reflect on his/her own individual consumer behavior in light of the needs of the natural world, other people, cultures and countries, and future generations; (2) Socio-emotional Learning Objective 2 of SDG 12-The learner (in our case future pre-primary teachers) is able to encourage others to engage in sustainable practices in education and production; and (3) Socio-emotional Learning Objective 1 of SDG 12-The learner is able to communicate the need for sustainable practices in production and consumption.

After answering the two research questions, Table 12 below offers a view of the global data of the research, showing the relationship and the difference between the sustainability competency (resulting from the pre and post-test highlighted in grey in the table) and the competency in education for sustainability per student (resulting from the training of the subjects and subsequent design of projects on sustainable food). The scores presented between the pre and post-test show that $69 \%$ of the students improved in the sustainability competency, which is also observed through the results obtained in the Wilcoxon test. Thus, the training program carried out between the two tests to work on ESD through the four subjects to develop a global project favored the development of sustainability competencies at the same time.

The results of the table show the interrelation between the sustainability competencies and the competencies in education for sustainability. In this respect, it should be remembered that the sustainability competency, assessed in the pre and post-test, integrates the core sustainability competencies of the CRUE [9] including cognitive learning objective 5 SDG 4 and behavioral learning objective 1 SDG 12 [5]. In addition, the competency in education for sustainability (assessment of the projects) promotes responsibility for professional development through the degree specific competency DSC 7: analyze, reflect on, and develop points of view on the profession and competency as a teacher, and the same behavioral learning objective 1 SDG 12, which consists in planning, implementing and evaluating consumption-related activities using existing sustainability criteria [5] (p. 34).

The results obtained show that the project method performed by the students has enabled them as future teachers to carry out actions related to achieving the SDGs in early childhood classrooms [5].

To reach this outcome, the educational method performed reflects the principles of active pedagogy as outlined in SDG 4, through the project method. We note that "the most appropriate way to accomplish in-depth learning is to achieve the involvement, effort and personal work of the student" [51] (p. 75). This author also emphasises the importance of the project method and recommends increasing its use in the university classroom. Likewise, the multidisciplinary and transdisciplinary work of the teachers who coordinated the subjects involved in the study is a key element, though not widely used, in the methodological renovation of higher education systems the EHEA aims for [2].

According to García, Junyent, and Fonolleda [52] assessing professional competencies in education for sustainability is complex and although there are recent studies that offer tools in this regard [43,53], there is still a lack of research that allows assessing the existence of changes or improvements in the professional knowledge of university students [54,55].

The scientific contribution of this article lies in providing assessment tools and evidence of the suitability of the project method as a global learning methodology coordinated among several didactic subjects to promote sustainability competency and competency in education for sustainability. Those instruments consist of training programs including appropriate educational models to develop both types of competencies [44]. In the case of students who will soon teach the citizens of the future, faculties of education have the duty and responsibility to ensure training that allows them to meet the objectives of sustainable development. It is for this reason that the present study presents this research as a sample of the complementarity between the sustainability competencies and those in education for sustainability. 
Table 10. Results of the assessment of the competency in ESD in groups (Instrument 2).

\begin{tabular}{|c|c|c|c|c|c|c|c|c|c|c|c|c|c|c|c|c|c|}
\hline \multicolumn{18}{|c|}{ Competencies in Education for Sustainability (ESD) Assessed at the Group Level } \\
\hline \multicolumn{18}{|c|}{$\begin{array}{l}\text { SSC adapted to SDG } 12 \\
\text { Encourage responsibility related to professional development: analyze, reflect on, and develop points of view that allow students to plan, implement and evaluate consumption-related using } \\
\text { existing sustainability criteria }\end{array}$} \\
\hline Indicators & & \multicolumn{3}{|c|}{$\begin{array}{l}\text { Interrelates food with the } \\
\text { environment and } \\
\text { socio-economic aspects }\end{array}$} & \multicolumn{3}{|c|}{$\begin{array}{l}\text { Presents an educational } \\
\text { project promoting } \\
\text { sustainable food in a } \\
\text { coordinated manner }\end{array}$} & \multicolumn{3}{|c|}{$\begin{array}{l}\text { Knows how to work } \\
\text { cooperatively and } \\
\text { responsibly }\end{array}$} & \multicolumn{3}{|c|}{$\begin{array}{l}\text { Justifies didactic learning } \\
\text { and thoughts developed } \\
\text { throughout the project }\end{array}$} & \multicolumn{3}{|c|}{$\begin{array}{l}\text { Communicates well and } \\
\text { uses appropriate } \\
\text { vocabulary }\end{array}$} & \multirow[b]{2}{*}{$\begin{array}{l}\text { Final } \\
\text { group } \\
\text { average }\end{array}$} \\
\hline $\begin{array}{l}\text { Levels of } \\
\text { competency }\end{array}$ & students & $\begin{array}{c}\text { Low } \\
1,2,3,4\end{array}$ & $\begin{array}{l}\text { Medium } \\
5,6,7\end{array}$ & $\begin{array}{l}\text { High } \\
8,9,10\end{array}$ & $\begin{array}{c}\text { Low } \\
1,2,3,4\end{array}$ & $\begin{array}{l}\text { Medium } \\
5,6,7\end{array}$ & $\begin{array}{l}\text { High } \\
8,9,10\end{array}$ & $\begin{array}{c}\text { Low } \\
1,2,3,4\end{array}$ & $\begin{array}{c}\text { Medium } \\
5,6,7\end{array}$ & $\begin{array}{l}\text { High } \\
8,9,10\end{array}$ & $\begin{array}{c}\text { Low } \\
1,2,3,4\end{array}$ & $\begin{array}{c}\text { Medium } \\
1,2,3,4\end{array}$ & $\begin{array}{l}\text { High } \\
8,9,10\end{array}$ & $\begin{array}{c}\text { Low } \\
1,2,3,4\end{array}$ & $\begin{array}{l}\text { Medium } \\
5,6,7\end{array}$ & $\begin{array}{l}\text { High } \\
8,9,10\end{array}$ & \\
\hline $\begin{array}{l}\text { Welcome to } \\
\text { Slowtering }\end{array}$ & $\mathrm{f}, \mathrm{n}, \mathrm{o}$ & \multicolumn{3}{|c|}{9.58} & \multicolumn{3}{|c|}{9.17} & \multicolumn{3}{|c|}{10.00} & \multicolumn{3}{|c|}{8.33} & \multicolumn{3}{|c|}{9.58} & 9.3 \\
\hline $\begin{array}{l}\text { Luigi, shall } \\
\text { we make an } \\
\text { eco-pizza? }\end{array}$ & $\mathrm{a}, \mathrm{g}, \mathrm{h}, \mathrm{k}$ & \multicolumn{3}{|c|}{9.44} & \multicolumn{3}{|c|}{9.72} & \multicolumn{3}{|c|}{10.00} & \multicolumn{3}{|c|}{8.47} & \multicolumn{3}{|c|}{10.00} & 9.5 \\
\hline Sugars & $\mathrm{c}, \mathrm{d}, \mathrm{p}$ & \multicolumn{3}{|c|}{7.66} & \multicolumn{3}{|c|}{8.44} & \multicolumn{3}{|c|}{9.38} & \multicolumn{3}{|c|}{8.13} & \multicolumn{3}{|c|}{9.38} & 8.6 \\
\hline $\begin{array}{l}\text { Eco-friendly } \\
\text { snacks }\end{array}$ & $\mathrm{e}, \mathrm{i}, 1$ & \multicolumn{3}{|c|}{7.34} & \multicolumn{3}{|c|}{9.22} & \multicolumn{3}{|c|}{8.44} & \multicolumn{3}{|c|}{6.72} & \multicolumn{3}{|c|}{8.44} & 8.0 \\
\hline Eco-smoothies & $\mathrm{b}, \mathrm{j}, \mathrm{m}$ & \multicolumn{3}{|c|}{8.91} & \multicolumn{3}{|c|}{9.53} & \multicolumn{3}{|c|}{8.75} & \multicolumn{3}{|c|}{8.59} & \multicolumn{3}{|c|}{9.38} & 9.0 \\
\hline $\begin{array}{l}\text { Average per } \\
\text { indicator }\end{array}$ & & \multicolumn{3}{|c|}{8.6} & \multicolumn{3}{|c|}{9.2} & & 9.3 & & & 8.05 & & & 9.4 & & 8.9 \\
\hline
\end{tabular}


Table 11. Results of the assessment of the competency in education for sustainable development (ESD)-at the individual level.

\begin{tabular}{|c|c|c|c|c|c|c|c|c|c|}
\hline Category & \multicolumn{9}{|c|}{ Competencies in ESD Assessed through Didactics } \\
\hline \multirow[t]{3}{*}{ Competencies } & $\begin{array}{l}\text { SSC (LNSSS) } \\
\text { ADAPTED to } \\
\text { SDG } 4 \text { and } 12 \\
\text { Draws up } \\
\text { teaching } \\
\text { proposals } \\
\text { related to the } \\
\text { interaction of } \\
\text { science, } \\
\text { technology, } \\
\text { society, and } \\
\text { sustainable } \\
\text { development }\end{array}$ & $\begin{array}{l}\text { SSC (LM) } \\
\text { ADAPTED to SDG } \\
4 \text { and } 12 \\
\text { Understands } \\
\text { mathematics as } \\
\text { socio-cultural } \\
\text { knowledge which } \\
\text { enables } \\
\text { differentiating } \\
\text { between needs and } \\
\text { wants and reflects } \\
\text { on consumer } \\
\text { behavior }\end{array}$ & $\begin{array}{l}\text { SSC (LL) } \\
\text { ADAPTED to } \\
\text { SDG } 4 \text { and } 12 \\
\text { Favors } \\
\text { speaking and } \\
\text { writing skills } \\
\text { over the need } \\
\text { for } \\
\text { sustainable } \\
\text { practices in } \\
\text { production } \\
\text { and } \\
\text { consumption }\end{array}$ & $\begin{array}{l}\text { SSC (PM) } \\
\text { ADAPTED to SDG } 4 \\
\text { and } 12 \\
\text { Promotes interest and } \\
\text { respect for the natural, } \\
\text { social, and cultural } \\
\text { environment through } \\
\text { appropriate teaching } \\
\text { projects that encourage } \\
\text { others to engage in } \\
\text { sustainable practices in } \\
\text { consumption }\end{array}$ & \multicolumn{4}{|c|}{$\begin{array}{l}\text { DSC ADAPTED to SDG } 4 \text { and } 12 \\
\text { Promotes responsibility in terms of professional development: to } \\
\text { analyze, reflect on and develop points of view allowing the student } \\
\text { to plan, implement and evaluate activities related to sustainable } \\
\text { food using existing sustainability criteria }\end{array}$} & \multirow[t]{2}{*}{$\begin{array}{l}\text { Difference } \\
\text { scores }\end{array}$} \\
\hline & \multicolumn{4}{|c|}{$\begin{array}{l} \\
\text { Subjects } \\
\end{array}$} & \multicolumn{4}{|c|}{ Global Didactic Project on sustainable food } & \\
\hline & $\begin{array}{c}\text { Scores LNSSS } \\
\text { EI }\end{array}$ & Scores LM & Scores LL & Scores PM & $\begin{array}{l}\text { Average score } \\
\text { subjects }\end{array}$ & $\begin{array}{l}\text { Individual } \\
\text { project (IP) }\end{array}$ & $\begin{array}{l}\text { Group Project } \\
\text { (GP) }\end{array}$ & $\begin{array}{c}\text { Average Score } \\
\text { IP-GP }\end{array}$ & $\begin{array}{c}\text { Difference } \\
\text { average score } \\
\text { subjects/Project } \\
\text { global } \\
\end{array}$ \\
\hline \multicolumn{10}{|l|}{ Students } \\
\hline $\mathrm{a}$ & 8.6 & 7.8 & 8.7 & 9.5 & 8.7 & 9.1 & 9.5 & 9.3 & 0.6 \\
\hline $\mathrm{b}$ & 8.5 & 6.6 & 7.5 & 8.2 & 7.7 & 6.6 & 9 & 7.8 & 0.1 \\
\hline $\mathrm{c}$ & 8.1 & 8.5 & 7.3 & 8.5 & 8.1 & 5.6 & 8.6 & 7.1 & -1.1 \\
\hline $\mathrm{d}$ & 8.1 & 6.6 & 7.6 & 8.6 & 7.7 & 7.6 & 8.6 & 8.1 & 0.3 \\
\hline e & 7.5 & 5 & 6.5 & 8.3 & 6.8 & 8.8 & 8 & 8.4 & 1.6 \\
\hline $\mathrm{f}$ & 7.3 & 5.6 & 7.1 & 9 & 7.3 & 8.5 & 9.3 & 8.9 & 1.6 \\
\hline $\mathrm{g}$ & 8.3 & 9 & 8.5 & 9.4 & 8.8 & 8.1 & 9.5 & 8.8 & -0.1 \\
\hline $\mathrm{h}$ & 8.8 & 7.5 & 9.1 & 9.7 & 8.8 & 8.5 & 9.5 & 9.0 & 0.2 \\
\hline $\mathrm{i}$ & 7 & 7 & 6.5 & 8.1 & 7.2 & 7 & 8 & 7.5 & 0.4 \\
\hline$j$ & 7.8 & 7.1 & 8.2 & 8.5 & 7.9 & 9 & 9 & 9.0 & 1.1 \\
\hline $\mathrm{k}$ & 7.5 & 7.5 & 8.2 & 9.3 & 8.1 & 7.5 & 9.5 & 8.4 & 0.3 \\
\hline 1 & 8.5 & 7.8 & 7.4 & 8.3 & 8.0 & 8.8 & 8 & 8.5 & 0.5 \\
\hline $\mathrm{m}$ & 8.5 & 9 & 8.6 & 8.8 & 8.7 & 8.6 & 9 & 8.8 & 0.0 \\
\hline $\mathrm{n}$ & 7.3 & 9 & 8.2 & 9.2 & 8.4 & 8.5 & 9.3 & 8.9 & 0.4 \\
\hline $\mathrm{O}$ & 7.3 & 7.2 & 7.5 & 9.1 & 7.8 & 8.3 & 9.3 & 8.8 & 1.0 \\
\hline$p$ & 7.6 & 7.7 & 8.2 & 8.7 & 8.1 & 7.6 & 8.6 & 8.1 & 0.0 \\
\hline
\end{tabular}


Table 12. Results of the assessment of the sustainability competency (SC) and the competency in education for sustainable development (ESD).

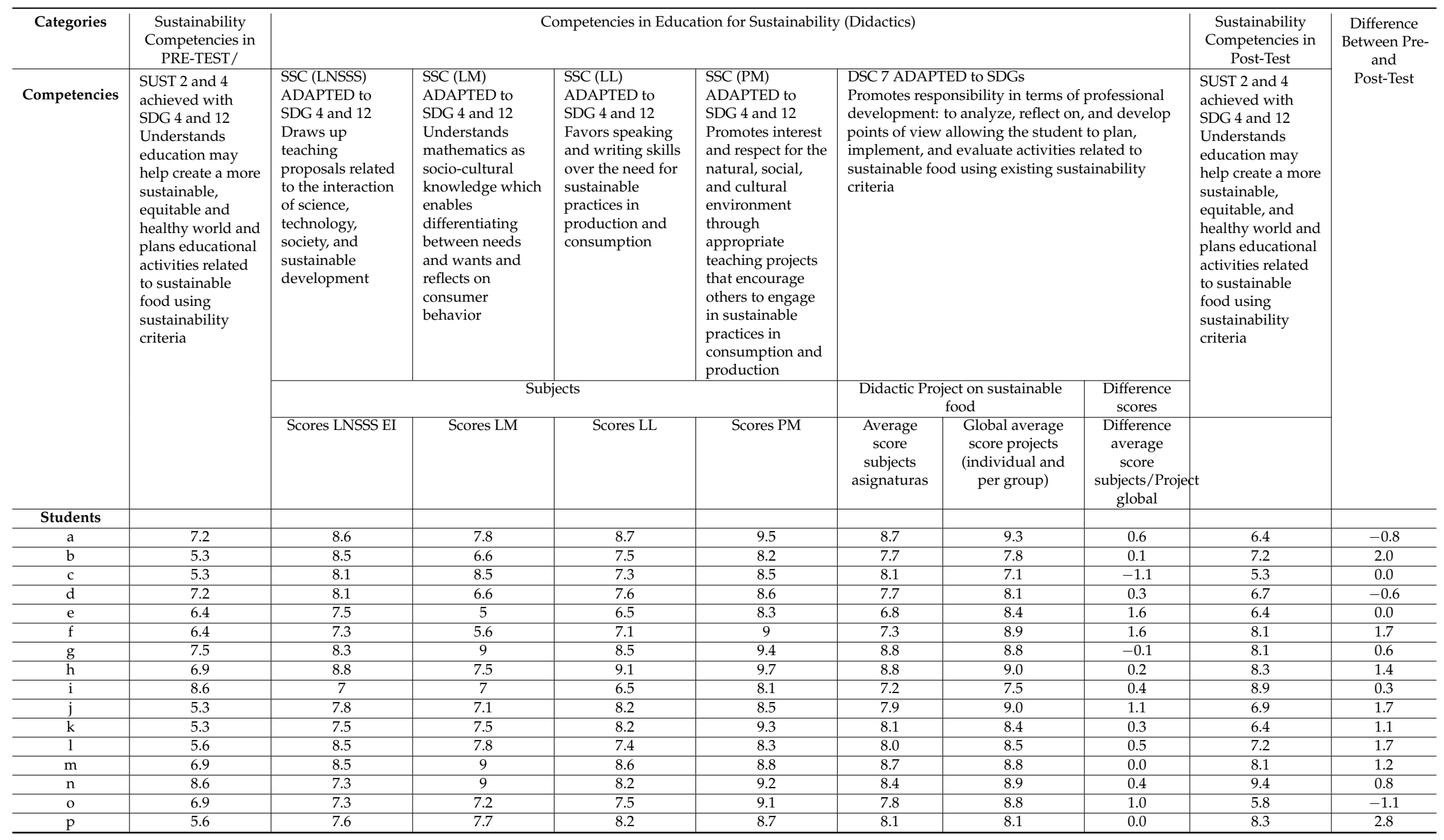


Training teachers for the education of future generations is key to achieve the objectives of SDG 4 based on ensuring inclusive, equitable quality education, and promoting lifelong learning opportunities for all [5], integrating the competencies for sustainability in higher education programs [25]. The project method uses scientific procedures that favor competency-based learning and not only knowledge transfer. According to Lambrechts and Van Petegem [35] and Jickling and Wals [14], competency-based higher education should allow the use of active teaching and learning methodologies in which the mental activity of the student to build knowledge is key. This mental activity implies the use of skills related to reflective thinking, critical thinking and decision-making. Those skills are necessary to develop scientific competency, and they offer the students a critical view of sustainability at an individual and professional level.

The research questions in this study, namely, (1) does planning projects on sustainable food related to SDG 4 and SDG 12 improve future teachers' sustainability competencies? (2) Does the design and implementation of global didactic projects improve future teachers' competencies in education for sustainability? Both obtained affirmative answers.

Within the framework of this research and using the related instruments, the analysis of the students' results in the assessments statistically shows they improved the sustainability competencies and those in education for sustainability.

The empirical study presented here provides evidence on the contribution made by education for sustainability, through the project method, combining knowledge, know-how, knowing how to be, and how to live with others [18]. It may be confirmed that the improvement in sustainability competencies and in education for sustainability, shown in the entire group, implies, as determined by the definition of the competency that students have improved with respect to knowing, knowing how to do and knowing how to be. It also presents evidence on the sustainability competencies of future teachers at an individual level.

According to UNESCO [5], sustainable development begins with education. The need to provide quality education to the greatest number of people is present in all the new goals proposed. The purpose of education must be that all learners acquire the knowledge and skills they need to thrive in a world where change is constant and learning never stops. In order to adapt to a constantly changing world, core competencies, such as problem solving, critical thinking, communication, etc. need to be developed that favor sustainable development. The relation between the competencies is that they are all core competencies that enable lifelong learning. If all learners need and deserve learning opportunities to thrive as tomorrow's leaders, workers, and citizens, we ask ourselves how we can train those future leaders without taking sustainability into account. Sustainability is key to train people to be able to face the challenges of the future and respect lifestyles in line with the environment and social justice.

As Fernández, Fuertes, and Albareda conclude [32], curricular sustainability involves not only including environmental content in initial teacher training, but also requires a paradigm shift in educational processes. This change also implies effectively integrating core sustainability competencies. In this study the core competencies of the CRUE [9] were used in combination with the specific competencies of the degree and of the different subjects [46-49] and with learning objectives from SDGs 4 and 12 [5].

Although this study was carried out with a limited sample, the results and discussion allow us to suggest a potential line of work to jointly develop the competency in education for sustainability and the sustainability competency from a holistic approach using the project method in higher education.

To sum up, this research shows that by developing competencies in education for sustainability through the project method, the participating students improved their individual sustainability competencies. After checking the literature, we believe our study provides evidence on the work carried out regarding sustainability competencies in the professionalization of future Early Childhood Education teachers. 
Author Contributions: Conceptualization, M.T.F.-C., M.C.B.-F., M.G.-M. and M.F.-L.; methodology, M.T.F.-C., M.C.B.-F. and M.G.-M.; validation, M.T.F.-C. and M.C.B.-F.; formal analysis, M.T.F.-C., M.C.B.-F., M.G.-M. and M.F.-L.; investigation, M.T.F.-C., M.C.B.-F. and M.G.-M.; resources, M.T.F.-C., M.C.B.-F., M.G.-M. and M.F.-L.; data curation, M.T.F.-C. and M.C.B.-F.; writing-original draft preparation, M.T.F.-C., M.C.B.-F., M.G.-M. and M.F.-L.; writing-review and editing, M.T.F.-C. and M.C.B.-F.; visualization, M.T.F.-C.; supervision, M.T.F.-C.; project administration, M.T.F.-C. and M.C.B.-F.; funding acquisition, M.T.F.-C., M.C.B.-F., M.G.-M. and M.F.-L.

Funding: This research was funded by the government of Catalonia and AGAUR in the call for the ARMIF 2015 project "Global plan of integrating mathematical, scientific and linguistic competencies in pre-service teacher training" (ref. 2015 ARMIF 00044) and the call for the ARMIF 2017 project "Work-linked training: a space for research and the construction of professional knowledge" (ref. 2017 ARMIF 00001].

Acknowledgments: We would like to thank Ann Swinnen for her feedback and comments and also gratefully acknowledge the support of the Integral Research Group on Sustainability and Education (SEI in Spanish) of the Universitat Internacional de Catalunya (2017 SGR 119).

Conflicts of Interest: The authors declare no conflict of interest.

\section{References}

1. Ull, M.A. Competencias para la sostenibilidad y competencias en educación para la sostenibilidad en la educación superior. Uni-Pluri/Versidad 2014, 14, 46-58.

2. Deloitte Risk Management in a VUCA Environment. 2016. Available online: https:/ /www2.deloitte.com/ $\mathrm{kh} / \mathrm{en} / \mathrm{pages} /$ risk/articles/risk-management-in-vuca-environment.html (accessed on 28 May 2018).

3. Sleurs, W. Competencies for ESD (Education for Sustainable Development) Teachers: A Framework to Integrate ESD in the Curriculum of Teacher Training Institutes. In Comenius 2.1 Project 118277-CP-1-2004-BE-Comenius-C2.1.; Sleurs, W., Ed.; Brussels, 2008; Available online: http:/ /www.unece. org/fileadmin/DAM/env / esd/inf.meeting.docs/EGonInd/8mtg/CSCT\%20Handbook_Extract.pdf (accessed on 15 March 2011).

4. Puig, J. Educar és ensenyar a viure. Fundació Catalana de l’Esplai: Movidic, El Prat de Llobregat, Spain, September 2018.

5. UNESCO 2017 Education for Sustainable Development Goals_Learning Objectives; UNESCO: París, France, 2017; ISBN 978-92-3-100209-0.

6. Cebrián, G.; Junyent, M. Competencies in Education for Sustainable Development: Exploring the Student Teachers' Views. Sustainability 2015, 7, 2768-2786. [CrossRef]

7. Stibbe, A. The Handbook of Sustainability Literacy: Skills for a Changing World; Stibbe, A., Ed.; Green Books: Devon, UK, 2009.

8. Aznar, P.; Solís, A. La formación de competencias básicas para el desarrollo sostenible: El papel de la universidad. Rev. Educ. 2009, 219-237. [CrossRef]

9. CRUE-Sustainability Guidelines for the Inclusion of Sustainability in the Curriculum. 2012. Available online: http:/ / www.crue.org/Documentos\%20compartidos/Declaraciones/Directrices_Ingles_ Sostenibilidad_Crue2012.pdf (accessed on 2 May 2018).

10. Ull, M.A.; Martínez-Agut, M.P.; Piñero, A.; Aznar Minguet, P. Análisis de la introducción de la sostenibilidad en la enseñanza superior en Europa: Compromisos institucionales y propuestas curriculares. Rev. Eureka sobre Enseñanza y Divulg. las Ciencias 2010, 7, 413-432. [CrossRef]

11. Tilbury, D. Education for Sustainable Development: An Expert Review of Processes and Learning. UNESCO: Paris, France, 2011. Available online: http://unesdoc.unesco.org/images/0019/001914/191442e.pdf (accessed on 5 June 2018).

12. González, J.; Wagenaar, R. Tuning Educational Structures in Europe; Universidad de Deusto: Bilbao, Spain, 2003.

13. Junyent, M.; Geli, A.M. Education for sustainability in university studies: A model for reorienting the curriculum. Br. Educ. Res. J. 2008, 34, 763-782. [CrossRef]

14. Jicking, B.; Wals, A. Globalization and environmental education: Looking. J. Curric. Stud. 2008, 40, 1-21. [CrossRef]

15. Rychen, D.S.; Salganik, L.H. Key Competencies for a Successful Life and Well-Functioning Society; Rychen, D.S., Salganik, L.H., Eds.; Hogrefe Publishing: Boston, MA, USA, 2003. 
16. Wals, A.E.J. Mirroring, Gestaltswitching and transformative social learning: Stepping stones for developing sustainability competence Social Learning in Natural Resource Management View project UpSWiNG: Understanding game-based approaches for improving sustainable wat. Int. J. Sustain. High. Educ. 2010, 11, 380-390. [CrossRef]

17. UNECE Empowering Educators for a Sustainable Future. Tools for policy and practice workshops on competences in education for sustainable development UNESCO (2005). United Nations EC/CEP/ 2013, 165, 14-15.

18. Delors, J.; Carneiro, R.; Chung, F.; Geremek, B.; Gorham, W.; Kornhauser, A.; Manley, M.; Quero, M.P.; Savané, M.-A.; Singh, K.; et al. La Educación Encierra un Tesoro, Informe a la UNESCO de la Comisión Internacional Sobre la Educación Para el Siglo XXI (Compendio); UNESCO: París, France, 2010.

19. Rieckmann, M. Future-oriented higher education: Which key competencies should be fostered through university teaching and learning? Futures 2012, 44, 127-135. [CrossRef]

20. Wals, A.E.J.; Jickling, B. "Sustainability" in higher education: From doublethink and newspeak to critical thinking and meaningful learning. Int. J. Sustain. High. Educ. 2002, 3, 221-232. [CrossRef]

21. Trilling, B.; Fadel, C. 21st Century Skills: Learning for Life in Our Times; John Wiley \& Sons: Hoboken, NJ, USA, 2012.

22. UNECE. Learning for the Future: Competences in Education for Sustainable Development. Geneva, 2011, United Nations Economic Commission for Europe, Steering Committee on Education for Sustainable Development, 2012. Available online: https:/ / bit.ly/2M1kqoc (accessed on 28 April 2018).

23. Wals Arjen, E.J. Shaping the Education of Tomorrow: 2012 Full-Length Report on the UN Decade of Education for Sustainable Development; UNESCO: Paris, France, 2012.

24. Ploum, L.; Blok, V.; Lans, T.; Omta, O. Toward a Validated Competence Framework for Sustainable Entrepreneurship. Organización y Medio Ambiente 2018, 31, 113-132. [CrossRef]

25. Lambrechts, W.; Mulà, I.; Ceulemans, K.; Molderez, I.; Gaeremynck, V. The integration of competences for sustainable development in higher education: An analysis of bachelor programs in management. J. Clean. Prod. 2013, 48, 65-73. [CrossRef]

26. UNITED NATIONS. Transforming Our World: The 2030 Agenda for Sustainable Development. Resolution adopted by the General Assembly on 25 September 2015. Available online: http://www.un.org/en/ development/desa/population/migration/generalassembly/docs/globalcompact/A_RES_70_1_E.pdf (accessed on 28 April 2018).

27. Declaració de Talloires Declaración de Talloires. Available online: http:/ / www.tufts.edu/talloiresnetwork/ ?pid=17\&c=7 (accessed on 30 April 2018).

28. UNITED NATIONS. Bonn Climate Change Conference. 2009. Available online: https://unfccc.int/process / conferences / pastconferences/bonn-climate-change-conference-june-2009/Overview (accessed on 16 July 2018).

29. Barth, M.; Godemann, J.; Rieckmann, M.; Stoltenberg, U. Developing key competencies for sustainable development in higher education. Int. J. Sustain. High. Educ. 2007, 8, 416-430. [CrossRef]

30. Wals, A.E.J. Sustainability in higher education in the context of the UN DESD: A review of learning and institutionalization processes. Clean. Prod. 2014, 62, 8-15. [CrossRef]

31. Wiek, A.; Withycombe, L.; Redman, C.L. Key competencies in sustainability: A reference framework for academic program development. Sustain. Sci. 2011, 6, 203-218. [CrossRef]

32. Fernández Morilla, M.; Fuertes Camacho, M.T.; Albareda Tiana, S. Sostenibilización curricular en la educación superior: Propuesta metodológica. Opción 2015, 31, 284-304.

33. Thomas, I. Critical Thinking, Transformative Learning, Sustainable Education, and Problem-Based Learning in Universities. Transform. Educ. 2009, 7, 245-264. [CrossRef]

34. Jones, P.; Selby, D.; Sterling, S. More than the sum of their parts? Interdisciplinarity and sustainability. Sustain. Educ. 2010, 17-38.

35. Lambrechts, W.; Van Petegem, P. The interrelations between competencies for sustainable development and research competencies. J. Int. J. Sustain. High. Educ. 2015, 17, 776-795. [CrossRef]

36. Dewey, J. The child and the curriculum. In En Middle works of John Dewey, 2nd ed.; Southern Illinois University Press: Carbondale, IL, USA, 1902.

37. Dewey, J. Mi credo pedagógico. Available online: https://www.fceia.unr.edu.ar/geii/maestria/ TEMPORETTI/Dewey_Mi_credo_Pedagogico.pdf (accessed on 31 January 2019). 
38. Kilpatrick, W.H. The Project Method. The Use of the Purposeful Act in the Educative Process; Columbia University: New York, NY, USA, 1918.

39. Pecore, J.L. From Kilpatrick's Project Method to Project-Based Learning. In International Handbook of Progressive Education; University of West Florida: Pensacola, FL, USA, 2015; pp. 155-171.

40. Hernándes, F.; Ventura, M. La Organización del Currículum por Proyectos de Trabajo. El Conocimiento es un Calidoscopio; Graó: Barcelona, Spain, 2000.

41. Lozano, R.; Merrill, M.Y.; Sammalisto, K.; Ceulemans, K.; Lozano, F.J. Connecting Competences and Pedagogical Approaches for Sustainable Development in Higher Education: A Literature Review and Framework Proposal. Sustainability 2017, 9, 1889. [CrossRef]

42. Bisquerra, R. Metodología de la Investigación Educativa, 1st ed.; La Muralla: Madrid, Spain, 2004.

43. Miller, G. The assessment of clinical skills/competence/performance. Acad. Med. 1990, 65, 563-567. [CrossRef]

44. Albareda-Tiana, S.; Vidal-Raméntol, S.; Pujol-Valls, M.; Fernández-Morilla, M. Holistic Approaches to Develop Sustainability and Research Competencies in Pre-Service Teacher Training. Sustainability 2018, 10, 3698. [CrossRef]

45. Fuertes, M.T. Modelo de sistematización en los proyectos sociales de ApS (UIC). Hist. y Comun. Soc. 2014, 19, 175-186. [CrossRef]

46. UICa. Learning the Natural Sciences and Socials Sciences. Available online: https://www.uic.es/en/studiesuic/education/bachelors-degree-pre-school-education/curriculum (accessed on 10 September 2018).

47. UICb. Learning the Mathematics. Available online: https://www.uic.es/en/studies-uic/education/ bachelors-degree-pre-school-education/curriculum (accessed on 10 September 2018).

48. UICc. Learning Languages. Available online: https://www.uic.es/en/studies-uic/education/bachelorsdegree-pre-school-education/curriculum (accessed on 10 September 2018).

49. UICd. Learning the Natural Sciences, Socials Sciences and Mathematics. Available online: https: //www.uic.es/en/studies-uic/education/bachelors-degree-pre-school-education/curriculum (accessed on 10 September 2018).

50. UNESCO. La Educación sí Importa: Hacia el Cumplimiento de los Objetivos de Desarrollo del Milenio. Paris, France, 2010. Available online: https://docplayer.es/86405-La-educacion-si-importa-hacia-elcumplimiento-de-los-objetivos-de-desarrollo-del-milenio-odm.html (accessed on 15 April 2018).

51. De Miguel, M. Metodologías para optimizar el aprendizaje. Segundo objetivo del Espacio Europeo de Educación Superior. Rev. Interuniv. Form. Profr. 2006, 20, 71-91.

52. Garcia, M.R.; Junyent, M.; Fonolleda, M. How to assess professional competencies in Education for Sustainability? Int. J. Sustain. High. Educ. 2017, 18, 772-797. [CrossRef]

53. Sandri, O.; Holdsworth, S.; Thomas, I. Vignette question design for the assessment of graduate sustainability learning outcomes. Environ. Educ. Res. 2018, 24, 406-426. [CrossRef]

54. Shephard, K.; Harraway, J.; Lovelock, B.; Mirosa, M.; Skeaff, S.; Slooten, L.; Strack, M.; Furnari, M.; Jowett, T.; Deaker, L. Seeking learning outcomes appropriate for 'education for sustainable development' and for higher education. Assess. Eval. High. Educ. 2015, 40, 855-866. [CrossRef]

55. Sipos, Y.; Battisti, B.; Grimm, K. Achieving transformative sustainability learning: Engaging head, hands and heart. Int. J. Sustain. High. Educ. 2008, 9, 68-86. [CrossRef]

(c) 2019 by the authors. Licensee MDPI, Basel, Switzerland. This article is an open access article distributed under the terms and conditions of the Creative Commons Attribution (CC BY) license (http://creativecommons.org/licenses/by/4.0/). 